\section{Early Season Weed Competition Reduces Yield of Newly Planted Matted Row Strawberries}

\author{
Marvin P. Pritts ${ }^{1}$ and Mary Jo Kelly \\ Department of Horticulture, Cornell University, Ithaca, NY 14853-5908
}

Additional index words. Fragaria $\times$ ananassa, economic injury levels, herbicide, runnering, thresholds, Sorghum bicolor

\begin{abstract}
Competition from weeds and an interplanted sudangrass [Sorghum bicolor $(\mathrm{L}$.) Moensch, formerly $S$. sudanense (Piper) Stapf.] cover crop was allowed to occur in newlyplanted strawberries (Fragaria Xananassa Duch.) for varying lengths of time, and at different times during the growing season. Newly planted strawberries were most susceptible to weed and cover crop competition during the first 2 months after planting, as both runnering (stolon formation) and subsequent yield were impacted. In 1994-95, 1 month of weed competition in June reduced yield by $20 \%$, whereas 2 months of weed competition reduced yield by $65 \%$. However, 1 month of uncontrolled weed growth later in the growing season had little to no impact on yield, although weed biomass was much less then. Herbicide (napropamide) use alone was insufficient to prevent weed competition and yield reduction. In our study, yield was reduced $0.67 \mathrm{t} \cdot \mathrm{ha}^{-1}$ or $5.5 \%$ for each $100 \mathrm{~g} \cdot \mathrm{m}^{-2}$ of weed biomass. The data suggest that it is critical for growers to minimize weed competition early in the planting year when weed growth is greatest. Since an interplanted sudangrass cover crop displaced a portion of the weeds, it could be seeded later in the year to provide some weed suppression without a negative impact on yield. Chemical names used: $N, N$, Diethyl2-(1-naphthalenyloxy)-propionamide (napropamide); $N$-(phosphonomethyl)glycine (glyphosate).
\end{abstract}

The concept of thresholds in integrated pest management programs was developed first by entomologists, then applied by plant pathologists to manage disease. However, despite their proven potential for reducing pesticide inputs, the use of thresholds has not been widely adopted by weed scientists (Gholson, 1987; O’Donovan, 1996). Weeds and/or their seeds are present in most agricultural situations, and most herbicides, to be effective, must be applied before seedlings become established and an economic threshold is reached. As the crop grows, it may become less sensitive to weed competition, rendering any weed threshold extremely variable over time. Furthermore, growers are sensitive about the appearance of their fields, and may apply an herbicide even when weeds are not impacting crop productivity (Czapar et al., 1997). For these reasons, thresholds for weeds are not analogous to thresholds for other types of pests. Rather than attempting to determine a traditional weed biomass threshold that negatively impacts yield, we wanted to understand the effects of timing and duration of weed competition on strawberry yield.


for publication 9 Nov. 2000. We thank Eric Hanson, Ian Merwin, and Lailiang Cheng for helpful reviews of this manuscript. This study was partially funded through the New York State Integrated Pest Management Program. The cost of publishing this paper was defrayed in part by the payment of page charges. Under postal regulations, this paper therefore must be hereby marked advertisement solely to indicate this fact.

${ }^{1}$ To whom requests for reprints should be addressed. E-mail address: mpp3@cornell.edu
}

In strawberry, only one preemergence herbicide (napropamide) is labeled for use nationally in the United States during the first growing season, and this herbicide provides $\approx 6$ to 8 weeks of control. An understanding of when weed competition is most detrimental to crop performance is critical for maximizing herbicide efficacy and for determining when to implement expensive hand weeding or mechanical cultivation practices.

The objectives of our study were to: 1) determine when strawberry plants are the most and least susceptible to competition during the planting year; and 2) determine the length of time required for weed competition to negatively impact strawberry plant growth and yield.

\section{Materials and Methods}

Studies were conducted at the Cornell Orchards in Ithaca, N.Y. Although the soil at this site is highly variable because of previous glacial activity, it is predominantly a Hudson silty clay loam (mixed, mesic, Typic Hapludalf). Sites were treated with $1.45 \mathrm{~kg} \cdot \mathrm{ha}^{-1}$ a.i. glyphosate (Roundup ${ }^{\circledR}$ ), then planted with the cultivar Jewel, and grown in a matted row production system. Standard cultural practices were followed throughout the studies (Pritts and Handley, 1998), including the application of $100 \mathrm{~kg} \cdot \mathrm{ha}^{-1} \mathrm{~N}$ as calcium nitrate. Except for weed control, pest management was based on need and followed commercial recommendations (Pritts et al., 1994). Predominant weed species present at the site included yellow nutsedge (Cyperus esculentus L.), common groundsel (Senecio vulgaris L.), purslane (Portulaca oleracea L.) and numer- ous grass (Graminae) species, particularly yellow foxtail [Setaria glauca (L.) Beauv.].

Weed-strawberry plant competition. The first experiment attempted to identify the period during strawberry plant establishment when weeds have the greatest and least impact on crop performance. Plots were tilled on 22 May 1994 and strawberries were planted $2 \mathrm{~d}$ later. Plants were set $0.5 \mathrm{~m}$ apart within rows and $1.5 \mathrm{~m}$ apart between rows. Individual plots consisted of three 3-m long rows, and data were collected from the middle row only.

Twelve treatments were imposed. Weeds were allowed to grow for various months (June, July, August, or September) or for various combinations of months (June and July; August and September; June, July, and August; July, August, and September; or June, July, August, and September). Plots were kept weed-free prior to and following these times by hand weeding, hoeing and/or mechanical cultivation. Two herbicide treatments and a weed-free control also were included. Napropamide herbicide (Devrinol ${ }^{\circledR}$ ) was applied at the standard post-planting rate $(2.2$ $\mathrm{kg} \cdot \mathrm{ha}^{-1}$ a.i.) and at twice the recommended rate (4.5 kg.ha- ${ }^{-1}$ a.i.) (Pritts et al., 1994). Treatments were arranged in a randomized complete-block design with four replications.

Weed biomass was assessed at the end of each competition period in an attempt to quantify the intensity of weed pressure. Weeds were harvested from a $1-\mathrm{m}^{2}$ area in the center of each plot, then separated by species, and fresh weights were recorded. Tensiometers (Irrometer Co., Riverside, Calif.) were set in rows at a 15 -cm depth to monitor soil moisture status in plots in which weeds were permitted to grow all season and in those that were maintained weed-free. In November, the number of rooted daughter plants in a 1-m section of row was recorded and all plots were then hand-weeded and cultivated. Napropamide at $4.5 \mathrm{~kg} \cdot \mathrm{ha}^{-1}$ a.i. was then applied, just prior to the application of winter rye (Secale cereale L.) mulch. The mulch was removed from the plants in late March and placed between rows. Few spring weeds were present in 1995 regardless of treatment.

All fruit from a 2-m-long section of row were harvested every 2 to $3 \mathrm{~d}$ from 16 June through 6 July 1995 . Total yield was recorded and no less than a 1-kg subsample was counted and weighed at each harvest for determining a weighted seasonal average for an individual fruit. Analysis of variance (ANOVA) was used to determine if differences existed among treatments, and regression analysis was used to determine the relationship between weed biomass and yield (SuperANOVA, Abacus Concepts, Berkeley, Calif.)

Cover crop-strawberry plant competition. A second experiment examined the ability of a cover crop to suppress weed growth, and compared the competitiveness of the cover crop with that of a naturally occurring weed population.

Plots were tilled prior to planting on 9 May 1995. The cultivar Jewel was planted on 0.5 -m centers in-row, and 1.25 -m centers between-rows. Plots were $3 \mathrm{~m}$ long $\times 2.5 \mathrm{~m}$ wide, 
and contained three rows of plants. Only the center row was used for data collection.

Eleven treatments were examined. Sudangrass was selected as an interplanted cover crop because it becomes established rapidly and grows quickly under warm temperatures, as do many weed species. Sudangrass was seeded at a rate of $100 \mathrm{~kg} \cdot \mathrm{ha}^{-1} \approx 7 \mathrm{~d}$ before the first of each month and irrigated so emergence would occur at the beginning of the month. Sudangrass or native weeds were permitted to grow for a 1-month period during the growing season (June-September), or for all 4 months. Hand weeding, hoeing, and/or cultivation were employed to keep the plots free of noncrop species at the appropriate times. A weed-free control was used as a standard for determining yield reductions. At the end of the season, all plots were hand-weeded and cultivated. Treatments were replicated four times, and arranged in a completely randomized design.

Weed biomass in a $1-\mathrm{m}^{2}$ area was measured at the end of each month-long period, or at the end of the season for the full-season competition treatment. Cover crop biomass, when present, also was recorded. Plant density and runner number were determined in late fall from a 1-m long section of row, then all weeds were removed from the plots by handweeding and cultivation. Winter rye mulch was applied in late autumn and removed in early spring, at which time napropamide (4.5 $\mathrm{kg} \cdot \mathrm{ha}^{-1}$ a.i.) was applied.

Fruit were harvested from a 2-m-long section of row every 2 to $3 \mathrm{~d}$ for a 2 -week period, beginning on 19 June 1996, and data were recorded and analyzed as for the previous experiment.

\section{Results and Discussion}

Yield in the fruiting year tended to decrease the earlier in the planting year that weed competition occurred (Table 1). One month of weed competition in June 1994 reduced yield in 1995 (20\% in comparison to weed-free plots), whereas competition in both June and July reduced yield $65 \%$, and uncontrolled weed growth for the entire planting year, reduced it $90 \%$. However, 1-month of uncontrolled weed growth in September did not significantly affect yield. The use of a preemergence herbicide alone, at either rate, was insufficient to provide acceptable levels of weed control for the entire growing season. There was a tendency for lower yielding plots to have larger fruits (Table 1).

Similar trends were observed when sudangrass was used as a substitute for weeds. One month of sudangrass competition in September had no impact on yield, whereas 1 month of competition in June significantly reduced yield compared to the weed-free control (Table 2). We were unsuccessful at establishing sudangrass plots of equal biomass during the 4 months of the study, despite equal seeding rates. However, weed biomasses in June, July, and September treatments in 1995 did not differ significantly, yet there was a significant increase in 1996 yield the later the weed competition occurred in 1995 (Table 2). Weed biomass itself was a good predictor of yield. In our study, yield was reduced 0.67 $\mathrm{t} \cdot \mathrm{ha}^{-1}$ or $5.5 \%$ for each $100 \mathrm{~g} \cdot \mathrm{m}^{-2}$ of weed biomass (Fig. 1).

Weed-free plots generally retained higher levels of soil moisture than did weedy plots throughout the growing season. Tensiometer readings in 1994, a relatively wet year, indicated that weed-free plots averaged $7.9 \mathrm{kPa}$ soil moisture tension during mid-summer, whereas weedy plots averaged $21.8 \mathrm{kPa}$ (eight dates, four plots/treatment, $\mathrm{SE}=8.7, P<0.01$ ). Competition with weeds for water can contribute to lower yields, but even in our weedy plots, soil moisture was relatively high. In addition, we applied relatively high levels of $\mathrm{N}$. Under our conditions of water and nutrient availability, competitive differences should have been minimized.

Despite adequate water and high rates of $\mathrm{N}$ fertilizer, early-season competition clearly had a negative impact on runnering or yield the following year, whereas late-season competition had little to no impact. Furthermore, the length of the competitive period was negatively associated with runnering and yield. However, weed competition is not necessarily uniform throughout the growing season. In our 1994-95 study, weed growth rates declined from June through September. Differences in weed growth between months may account for the smaller negative effect of weeds late in the season. Strawberry plants are also larger then, and will probably tolerate competition better than younger, smaller plants.

Several other studies have evaluated the effect of timing of weed competition on fruit crop productivity, and the results are remarkably similar. Lawson and Wiseman (1976) studied the effects of weeds on strawberry cv. Cambridge Favourite in Scotland. They allowed weeds to grow for various lengths of time from planting onward. Leaving weeds untouched until early July resulted in a major reduction in runner production, while plots left unweeded until late August produced few or no runners. They also found that weed regrowth after late weedings had no effect on runnering and yield. Merwin and Ray (1997) reported that the timing of weed suppression in young, irrigated apple trees (Malus $\times$ domestica Borkh.) is more important than the area of suppression beneath them, and that early summer weed control is especially important. Similarly, Al-Hinai and Roper (2001) reported that early season weed control is more important than late-season control for growth in tart cherry trees (Prunus cerasus L.).

Our results are consistent with those obtained in these studies and the conclusions are the same - weed competition early in the planting year has a major impact on productivity, whereas competition later in the season has little adverse effect. A grower still may wish to remove late season weeds so they will not contribute to the seed bank or so perennial weeds will not become established (O'Donovan, 1996), but removal of late season weeds will not directly impact next year's production potential.

Results of such studies could differ with a different spectrum of weed species, especially in a site heavily infested with fastgrowing perennials such as quackgrass [Elytriga repens (L.) Nevski]. However, our procedures are more representative of a commercial planting where an attempt was made to eliminate perennials prior to planting. In 1994, the only established perennial in the planting, nutsedge (Cyperus esculentus L.) comprised $<10 \%$ of the fresh weight of weeds in any given treatment (Table 1). In the 1995

Table 1. Effects of varying periods of weed competition (W) and rates of herbicide in 1994 on weed biomass at the end of treatment, runner production at the end of the season, and subsequent year's yield and fruit size of 'Jewel' strawberry. The treatment effect was significant for all variables at $P<0.05$.

\begin{tabular}{|c|c|c|c|c|c|c|c|c|c|c|c|}
\hline \multicolumn{4}{|c|}{ Treatment } & \multicolumn{5}{|c|}{ Weed fresh wt $\left(\mathrm{g} \cdot \mathrm{m}^{-2}\right)$} & \multirow{2}{*}{$\begin{array}{c}\text { Runners } \\
\text { (no./m) }\end{array}$} & \multirow{2}{*}{$\begin{array}{l}\text { Yield } \\
\left(\mathrm{g} \cdot \mathrm{m}^{-1}\right)\end{array}$} & \multirow{2}{*}{$\begin{array}{l}\text { Berry } \\
\text { wt }(g)\end{array}$} \\
\hline June & Jul. & Aug. & Sept. & Nutsedge & Grasses & $\mathrm{ABL}^{2}$ & $\mathrm{PBL}^{2}$ & Total & & & \\
\hline$\overline{---}$ & ---- & --- & --- & 0 & 0 & 0 & 0 & 0 & 47 & 1501 & 7.2 \\
\hline W & --- & --- & --- & 37 & 171 & 167 & 72 & 447 & 31 & 1204 & 7.2 \\
\hline --- & W & --- & --- & 5 & 7 & 42 & 2 & 56 & 26 & 1297 & 8.3 \\
\hline --- & --- & W & --- & 2 & 2 & 60 & 3 & 67 & 38 & 1534 & 7.5 \\
\hline--- & --- & -- & $\mathrm{W}$ & 0 & 2 & 3 & 2 & 7 & 42 & 1551 & 7.4 \\
\hline W & $\mathrm{W}$ & --- & --- & 16 & 552 & 617 & 94 & 1279 & 5 & 535 & 8.1 \\
\hline --- & --- & W & $\mathrm{W}$ & 1 & 53 & 180 & 109 & 343 & 34 & 1324 & 7.7 \\
\hline W & W & W & --- & 90 & 919 & 760 & 118 & 1887 & 1 & 265 & 9.7 \\
\hline--- & W & W & $\mathrm{W}$ & 26 & 381 & 382 & 113 & 902 & 21 & 900 & 9.7 \\
\hline W & W & W & W & 20 & 836 & 278 & 48 & 1182 & 1 & 146 & 9.7 \\
\hline \multicolumn{4}{|c|}{ Napropamide $\left(2.2 \mathrm{~kg} \cdot \mathrm{ha}^{-1}\right.$ a.i. $)$} & 54 & 317 & 783 & 72 & 1226 & 3 & 258 & 10.3 \\
\hline \multicolumn{4}{|c|}{ Napropamide $\left(4.5 \mathrm{~kg} \cdot \mathrm{ha}^{-1}\right.$ a.i. $)$} & 80 & 191 & 698 & 29 & 998 & 1 & 273 & 9.7 \\
\hline \multicolumn{4}{|c|}{$\operatorname{LSD}_{0.05}$} & 55 & 250 & 302 & 51 & 335 & 15 & 376 & 0.9 \\
\hline
\end{tabular}

${ }^{\mathrm{z}}$ Annual (ABL) and perennial (PBL) broadleaf weeds. 
Table 2. Effects of varying periods of weed (W) or sudangrass (S) competition on noncrop plant species biomass at the end of treatment, on runner production at the end of the season in 1995, and on yield and fruit size in 1996. The treatment effect was significant for all variables, except berry weight, at $P<0.05$.

\begin{tabular}{|c|c|c|c|c|c|c|c|c|c|c|c|c|c|}
\hline \multicolumn{4}{|c|}{ Treatment } & \multicolumn{7}{|c|}{ Weed fresh wt $\left(\mathrm{g} \cdot \mathrm{m}^{-2}\right)$} & \multirow{2}{*}{$\begin{array}{r}\text { Runners } \\
\text { (no./m) }\end{array}$} & \multirow{2}{*}{$\begin{array}{l}\text { Yield } \\
\left(\mathrm{g} \cdot \mathrm{m}^{-1}\right)\end{array}$} & \multirow{2}{*}{$\begin{array}{l}\text { Berry } \\
\text { wt (g) }\end{array}$} \\
\hline June & Jul. & Aug. & Sept. & Nutsedge & Grasses & $\mathrm{ABL}^{\mathrm{z}}$ & $\mathrm{PBL}^{\mathrm{z}}$ & Total W $\mathrm{W}^{\mathrm{z}}$ & $\mathrm{S}^{\mathrm{z}}$ & Total $\mathrm{W}+\mathrm{S}$ & & & \\
\hline $\begin{array}{l}-- \\
-\end{array}$ & --- & --- & --- & 0 & 0 & 0 & 0 & 0 & 0 & 0 & 35 & 984 & 11.0 \\
\hline S & --- & --- & --- & 315 & 23 & 12 & 7 & 357 & 393 & 750 & 17 & 604 & 9.8 \\
\hline --- & $\mathrm{S}$ & --- & --- & 252 & 29 & 28 & 4 & 313 & 668 & 981 & 25 & 808 & 9.9 \\
\hline--- & --- & $\mathrm{S}$ & --- & 25 & 5 & 328 & 5 & 363 & 529 & 892 & 22 & 607 & 10.8 \\
\hline --- & --- & --- & $\mathrm{S}$ & 3 & 1 & 89 & 5 & 98 & 161 & 259 & 32 & 1002 & 10.4 \\
\hline S & $\mathrm{S}$ & $\mathrm{S}$ & $\mathrm{S}$ & 1 & 13 & 3 & 2 & 19 & 1748 & 1767 & 2 & 90 & 9.4 \\
\hline W & --- & --- & --- & 323 & 59 & 213 & 32 & 627 & 0 & 627 & 19 & 483 & 9.4 \\
\hline--- & $\mathrm{W}$ & --- & --- & 518 & 41 & 242 & 9 & 810 & 0 & 810 & 16 & 722 & 10.0 \\
\hline --- & --- & W & --- & 25 & 26 & 1069 & 4 & 1124 & 0 & 1124 & 15 & 662 & 10.6 \\
\hline --- & --- & --- & W & 4 & 1 & 967 & 6 & 978 & 0 & 978 & 29 & 887 & 9.4 \\
\hline W & W & W & W & 10 & 129 & 140 & 306 & 585 & 0 & 585 & 6 & 355 & 10.9 \\
\hline $\mathrm{LSD}_{0.05}$ & & & & 176 & 64 & 260 & 86 & 290 & 289 & 381 & 11 & 336 & 1.7 \\
\hline
\end{tabular}

${ }^{\mathrm{z}}$ Annual broadleaf (ABL), perennial broadleaf (PBL), total weed (Total W), and sudangrass (S) biomass.

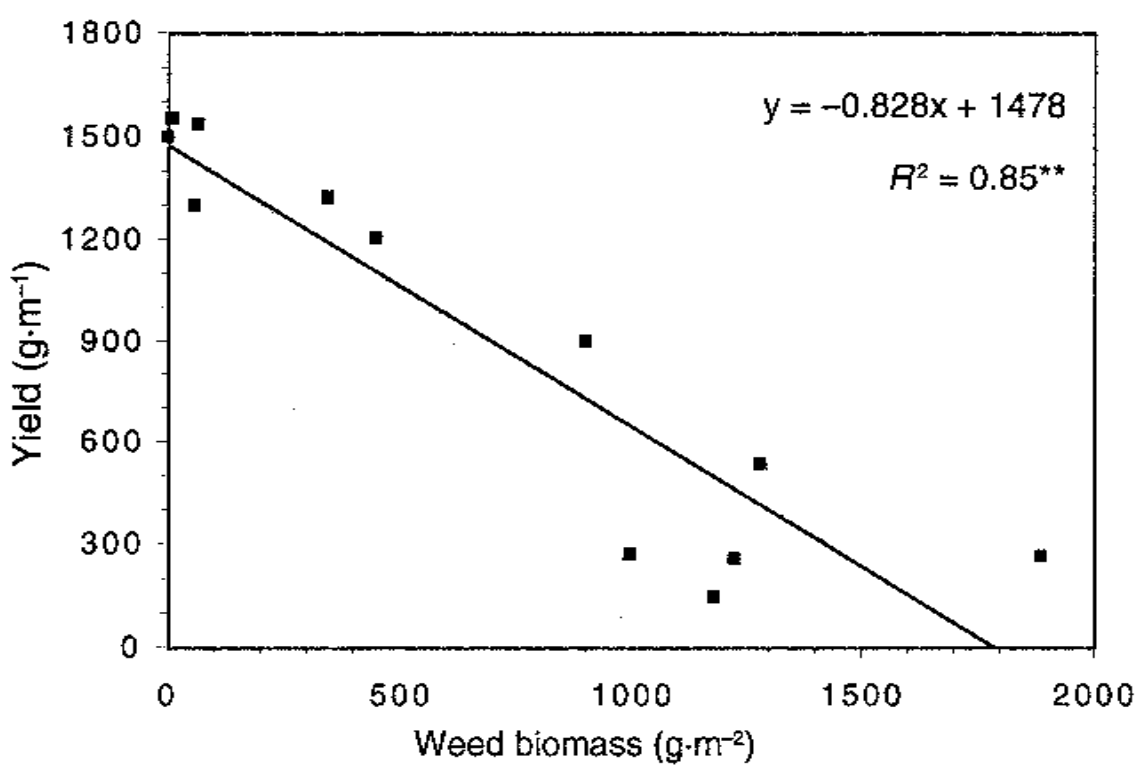

Fig. 1. Regression of productivity of 'Jewel' strawberry in the first fruiting year (1995) on weed biomass in the planting year $(1994)(P<0.01)$.

study site, nutsedge was much more abundant, yet the trends for these 2 years were the same (Table 2). This suggests that early season weed competition in the planting year, whether from annuals or perennials, typically will be more detrimental to strawberry productivity than late season competition, although thresholds may vary with location, weather and species composition. We did not obtain dry weights for weeds, but the trends probably would be similar, especially since more succulent weeds (i.e., purslane) were rather uniformly distributed throughout the site. Both provide an estimate of competition, and fresh weight can be measured easily by a grower to help determine if weed removal is warranted.

The practical implications of this study for growers are several. First, controlling treatments (Table 2). By seeding sudangrass late, competition with the strawberry plants will be minimal, the sudangrass will die at the first frost and not contribute seeds to the soil, and the residue will aid in the retention of straw mulch used for winter protection. Furthermore, this species suppresses root lesion nematodes [Pratylenchus penetrans (Cobb) Sher and Allen] (MacDonald and Mai, 1963). The effect of weed and/or cover crop competition also needs to be quantified in older plantings before competitive effects are completely understood and management options developed.

\section{Literature Cited}

Al-Hinai, Y.K. and T.R. Roper. 2001. Temporal effects of chemical weed control on tart cherry tree growth, yield, and leaf nitrogen concentration. HortScience 36:80-82.

Czapar, G.F., P.M. Curry, and M.L. Wax. 1997. Grower acceptance of economic thresholds for weed management in Illinois. Weed Technol. 11:828-831.

Gholson, L.E. 1987. Adaptation of current threshold techniques for different farm operations. Plant Dis. 71:462-465.

Lawson, H.M. and J.S. Wiseman. 1976. Weed competition in spring-planted strawberries. Weed Res. 16:345-354.

MacDonald, D.H. and W.F. Mai. 1963. Suitability of various cover crops as hosts for the lesion nematode, Pratylenchuspenetrans. Phytopathology 53:730-731.

Merwin, I.A. and J.A. Ray. 1997. Spatial and temporal factors in weed interference with newly planted apple trees. HortScience 32:633637.

O'Donovan, J.T. 1996. Weed economic thresholds: Useful agronomic tool or pipe dream? Phytoprotection 77:13-28.

Pritts, M. and D. Handley. 1998. Strawberry production guide for the Northeast, Midwest and eastern Canada. Northeast Regional Agr. Eng. Serv.-88, Ithaca, N.Y.

Pritts, M., W. Wilcox, J. Kovach, and A. Agnello. 1994. Pest management recommendations for small fruit crops. Cornell Univ., Ithaca, N.Y. 